\title{
Terapeutická intervencia prostriedkami výtvarnej výchovy pre žiakov so syndrómom ADHD
}

\section{Therapeutic Intervention by Means of Art Education for Pupils with ADHD Syndrome}

Alena Sedláková몽, Prešovská univerzita v Prešove, Pedagogická fakulta, Prešov

\begin{abstract}
Abstrakt
Náš príspevok Terapeutická intervencia prostriedkami výtvarnej výchovy pre žiakov so syndrómom ADHD prináša základné poznatky o syndróme ADHD a jeho terapii prostriedkami výtvarnej výchovy. $V$ príspevku tiež uvažujeme aj o arteterapii a jej spojitosti s výtvarnou výchovou. Čiastočne sa dotýkame aj artefiletiky, kedz̃e nám nejde o výsledné výtvarné dielo ale skôr o zážitok z tvorby. Intervencia je riešená prostriedkami vybranými z výtvarnej výchovy a súčasných výtvarných techník, ktoré pomáhajú zmierňovat' syndróm $A D H D$ v edukácii žiakov. Kladieme tak dôraz na výtvarné techniky a ich formy pre intervenciu. $V$ príspevku spomíname aj iné výtvarné prejavy, ktoré môžu byt prepojené aj s inými druhmi umenia. Uvažujeme o nich $v$ spojitosti s modernými výtvarnými metódami v rámci súčasného výtvarného umenia a umeleckých metód.
\end{abstract}

\section{Klíčová slova}

Syndróm ADHD, výtvarná výchova, umenie, intervencia.

\section{Abstract}

Our contribution Therapeutic intervention by means of the art education for pupils with ADHD syndrome brings basic knowledge about ADHD syndrome and its therapy by means of art education. In the article we also consider art therapy and its connection with art education. We also partly touch on artefiletics, as we are not interested in the final work of art, but rather in the experience of creation. The intervention is solved by means selected from art education and contemporary art techniques, which help alleviate the ADHD syndrome in the education of students. We place emphasis on art techniques and their forms for intervention. In the article, we also mention other artistic expressions that can be connected with other types of art. We consider them in connection with modern art methods within contemporary art and artistic methods.

\section{Keywords}

ADHD syndrome, art education, art, intervention.

\section{Úvod}

ADHD predstavuje Attention Deficit Hyperactivity Disorder. Je to hyperkinetická porucha a vo svete sa jej venuje mnoho priestoru. Ciel'om je zmierňovat' jeho negatívne prejavy a snažit' sa o dôstojné prežitie a výchovu. Táto neurovývojová porucha sa ale nedá úplne odstránit' ale v našich podmienkach, máme na mysli výtvarnú intervenciu pomocou výtvarných prostriedkov môžeme jej prejavy zmiernit.. Táto porucha sa zvyčajne prejavuje od útleho veku a preto sa ju snažíme riešit́ aj prostriedkami výtvarného umenia, či výtvarnej výchovy. Využívame k tomu aj techniky arteterapie a tiež aj artefiletiky. Okrem základných

prejavov ADHD sa u detí s touto diagnózou často stretávame aj s rôznymi pridruženými táažkost́ami. Aj tie 1 alena.sedlakova@unipo.sk 
sa snažíme eliminovat’ formami arteterapie, pravda okrem dôležitej a významnej farmakoterapie.

\section{Východiská ADHD v súčasných zdrojoch}

Viaceré výskumy potvrdili, že porucha pozornosti spojená s hyperaktivitou je jednou z najčastejšie sa vyskytujúcich psychických porúch u detí. Jedná sa o diagnózu, ktorá ovplyvňuje fungovanie diet́at́a vo všetkých oblastiach jeho života. U vel'kej časti detí príznaky pretrvávajú i do dospelosti a môžu viest́ k iným závažným psychickým poruchám. Včasné zahájenie terapie je nevyhnutné. Růžička a Vožechová (In Kroupová a kol. 2016) píšu, že ADHD je neurologická porucha postihujúca deti a dospelých. Prejavuje sa trvalými alebo priebežnými prejavmi nepozornosti, hyperaktivity či impulzivity. Jedinci s ADHD môžu mat' rovnako problémy s udržaním exekutívnych funkcií a pracovnou pamätóou. Porucha skôr označovaná ako l'ahká mozgová encefalopatia, neskôr ako minimálna, prípadne l'ahká mozgová dysfunkcia. Jedná sa o skupinu geneticky prenášaných neurovývojových dysfunkcií, ktoré u postihnutých osobách znižujú schopnost' zamerat' a udržat' pozornost', prispôsobovat' aktivitu a ovládat' impulzy. Rietzler a Grolimund (2016) píšu, že sa vyskytuje tiež porucha pozornosti alebo deficit pozornosti s poruchou aktivity. Deti s ADHD sa od ostatných detí odlišujú vo vnímaní sveta a v správaní. Rozdiely sú prevažne v oblasti pozornosti, hyperaktivite a impulzívnosti. Podl'a toho, ktorý symptóm prevažuje, rozlišuje klasifikačný systém DSM-5, aktuálny diagnostický a štatistický manuál psychických porúch tri typy: prevažujúce hyperaktívno-impulzívne správanie, prevažujúce deficity pozornosti a zmiešané správanie, označované aj ako kombinovaný typ. Goetz a Uhlíková (2013) uvádzajú aj to, že terminológia odráža aj pokrok vo výskumoch príčin, prejavov a liečby poruchy. Termín ADHD je štandardným vo väčšine vyspelých krajinách. Hlavné problémy, ktoré deti s ADHD majú, vyplývajú z narušenej schopnosti sústredit’ sa. Rodičia často hovoria, že ich zaujíma všetko okrem toho, čo ich zaujímat́ má. Sú akoby v dennom sne. Prejavy v chovaní u konkrétneho dietata sú dôsledkom kombinácie základných príznakov choroby, pridružených psychických poruchách a vplyvov prostredia. Ide aj o to, ako sa kto k dietatú chová, v akej rodine žije, aké má št́astie na učitel'ov a spolužiakov a aké má d’alšie charakteristiky osobnosti. Intenzita prejavov ADHD nie je stále rovnako silná. Kolíše nerovnomerne a pre deti a rodičov je nepredvídatel'ná. Tieto výkyvy v chovaní dietatáa a jeho výkonov pri rôznych činnostiach pôsobia na okolie až dojmom schválnosti. Diet́a je za to chybne kritizované a obviňované. Nemôžeme však zjednodušene povedat', že deti s ADHD majú celkovo zníženú schopnost' sústredit' sa, a že je vždy l'ahké ich vyrušit'. Det̂́om s ADHD vel'mi rýchlo zovšednie činnost', ktorou sa zaoberajú a vel'mi rýchlo sa dostaví nuda. Napríklad pestrá a premenlivá počítačová hra ich často dokáže zaujat́ dlhšie ako domáca úloha. Písanie domácich úloh im zaberá dlhší čas, pretože lipnú na detailoch. Deti s ADHD nie sú vytrvalé a ciel'avedomé. Aj otázka vnímania času je u nich problematická. Tiež majú problém so spánkom. Nie však u všetkých detí je nepozornost', hyperaktivita a impulzivita. Podl'a zastúpenia príznakov rozlišujeme aj tzv. subtypy ADHD. Niektoré deti majú skôr potiaže s pozornostou, ale nie sú hyperaktívne či impulzívne. Najčastejší je subtyp zmiešaný ADHD.

Diagnóza ADHD (Attention Deficit Hyperactivity Disorder) a ADD (Attention Deficit Disorder) sa dá s istotou stanovit́ až ked' ich príznaky dlhšiu dobu negatívne ovplyvňujú zvládanie každodenného života a podarí sa vylúčit iná príčina alebo dochádza k psychickému strádaniu. Podl'a Reimann-Höhn (2018) sa nepozornost́ prejavuje vo všetkých oblastiach života a má negatívny dopad hlavne v škole, pri učení alebo štúdiu. Dospievajúci sa dopúšt́ajú prehliadaniu detailov a z nepozornosti sa dopúšttajú aj mnohých chýb. Nedokážu sa sústredit' a majú problém s načúvaním. Začnú mnoho projektov, ale len máloktorý sa im podarí niektorý dokončit́. Dôkazy, že ADHD a ADD sprevádza vysoký intelekt neexistujú. V súčasnej dobe odborníci rozlišujú štyri rôzne druhy poruchy: 1. kombinovaná ADHD a ADD (zahŕňa všetky zložky), 2. prevažne nepozorný typ, 3. prevažne hyperaktívne impulzívny typ a 4. reziduálny typ (u mládeži a dospelých, u ktorých už nie sú výrazne zastúpené všetky skoršie príznaky. Odlišujú sa silou a prejavom príznakov. Slowík (2020) uvádza, že je dôležité upozornit', že syndrómy ADD i ADHD môžu mat' vcelku pestrú etiológiu, nemožno ich preto s l'ahkou mozgovou disfunkciou celkom stotožnit', pretože aj samotná lahká mozgová disfunkcia sa môže manifestovat' rovnako celkom inými symptómami, než práve ADD a ADHD.

\section{Terapeutická intervencia prostriedkami výtvarnej výchovy}

Okrem liekovej terapie sa dá jemne terapeuticky pôsobitt na deti a žiakov so syndrómom ADD a ADHD aj prostriedkami výtvarnej výchovy, či výtvarného umenia a jeho metódami, či hudbou - muzikoterapiou, ktoré sú tiež obsiahnuté aj v arteterapii a artefiletike. Niektoré umelecké metódy sú založené na vol'nom 
výtvarnom prejave, prepájajú do seba aj iné druhy umení - artefiletické aktivity s hl'adaním predmetov v prírode či ich prepájaním s rozkotúl'aným klbkom vlny k ostatným detóm a žiakom. Land art umožňuje tvorbu v prírode pomocou prírodných materiálov. Automatická kresba si vyžaduje spontánnost' a vol'ný prístup. Arteterapia pracuje aj s hlinou, umožňuje jej búchanie, miesenie a hádzanie. Dalej môžeme využí vat' metódu mozaiky z kamienkov, farebných listov zo stromov a kvetín. Podl'a Winter (2018) realizujeme učenie sa pohybom, získavanie skúseností a zručností, lebo deti so špecifickou vývojovou poruchou motorických funkcií alebo ADHD majú často potiaže s plánovaním pohybu a plánovaním činností. Upozorňuje na fázu kognitívnu, asociačnú a autonómnu, kde sa využíva opakovanie.

V arteterapii sa uplatňuje asociačná fáza tvorby pomocou akvarelových farieb. Môžeme mal'bu po ukončení roztrhat' na menšie časti a po krátkej relaxácii hudbou zlepíme natrhanú mal'bu do novej podoby koláže - pričom spontánne uplatníme rekonštrukciu, ako arteterapeutickú metódu.

Winter (2018) na inom mieste vysvetliuje, že len najdôležitejšie informácie dorazia do vel'kého mozgu. Z neuroanatómie a terapeutického výskumu vieme, že zvláštt spracovanie senzorických a motorických informácií je zodpovedné za obecnú reakčnú pripravenost' a bdelost' centrálnej nervovej sústavy.

Kedže syndróm ADD a ADHD je charakteristický aj problémom pozornosti, snažíme sa vo výtvarnej tvorbe realizovat' práce s odstupom a po častiach. Niekedy využívame skladanie papiera alebo jeho krčenie a pomal'ovanie, čím uplatníme muchláž. Ďalej je problémom aj roztržitost' a rozptýlenost́ a môžeme tu použit' miešanie farieb a ich fŕkanie na papier či väčšie plátno na ráme. Medzi jednotlivými aktivitami robíme vždy relaxačné prestávky, môžeme využit' muzikoterapiu. Taktiež môžeme použit' multimediálne médiá - počítač, tablet apod. K výtvarnej činnosti využívame aj xerografické reprodukcie známych umeleckých diel, ktoré deti a žiaci s ADD a ADHD môžu premal'ovávat' a tak vytvárat́ reinterpretácie. Možností je mnoho, no musíme metodické postupy prispôsobit' k danej situácii a stavu detí a žiakov. Niekedy môžeme pracovat' len s jedným diet́atom alebo žiakom, inokedy aj s viacerými.

\section{Výtvarné činnosti}

Na ilustráciu predkladáme zopár obrázkov, ktoré vznikli za podpory pedagógov k výtvarnej prezentácii. Ide o vol'nú tvorbu detí a žiakov, ktorí majú poruchu pozornosti a hyperaktivitu spojenú s ADHD.

Obr. 1 Budimírske studničky. Rozprávka. Kombi-

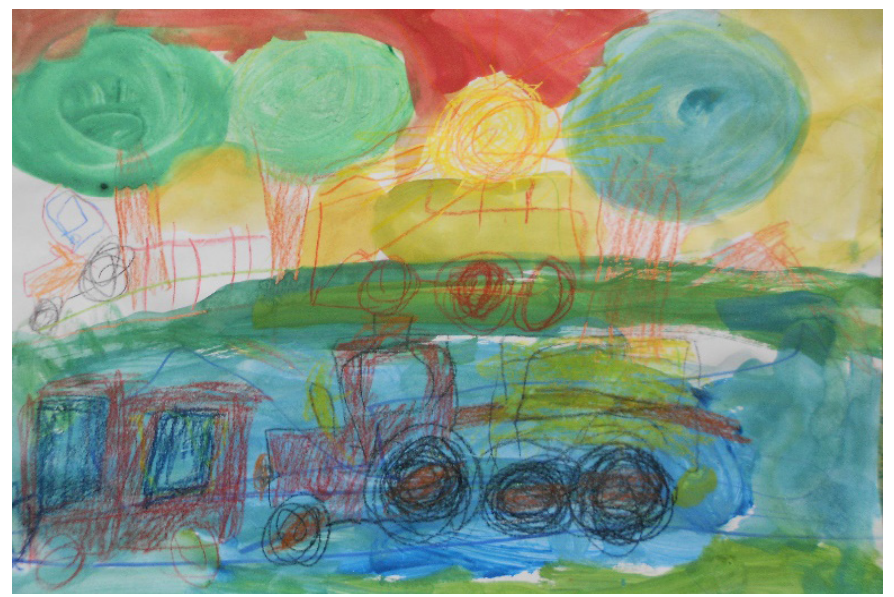

novaná technika akvarelu a pasteliek. Žiak, 10 rokov. Zdroj: Archív autorky.

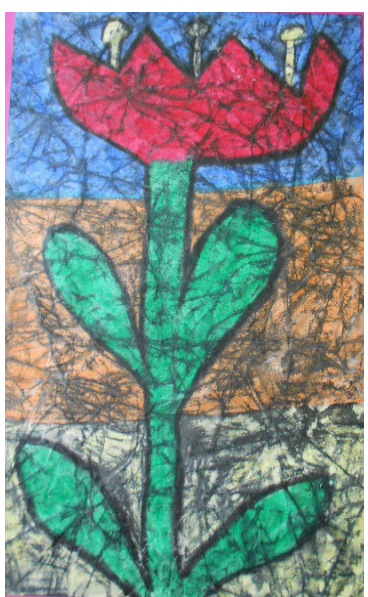

Obr. 2 Muchláž spojená s kresbou tušom. Žiačka 11 rokov. Zdroj: Archív autorky.

\section{Záver}

V príspevku sme sa zaoberali syndrómom ADHD, čiastočne aj ADD ako problémom, ktorý v sebe zahŕňa poruchu pozornosti a hyperaktivity. Uvažovali sme o jeho prejavoch, ktoré sprevádzajú deti od útleho veku až po dospelost.́. Ciel'om bolo práve poukázat' na prejavy ADHD a možnosti terapie a intervencie prostriedkami výtvarnej výchovy, arteterapie alebo metódami výtvarného umenia. Taktiež sme spomenuli možnost́ skúsit́ výtvarnú činnost' aj s prostriedkami artefiletiky, ktorá si síce nevyžaduje realizáciu dokonalého výtvarného diela, dôraz sa kladie na priebeh výtvarnej činnosti a reflektívny dialóg. Ten môže byt' pri syndróme ADHD väčším problémom, ale pri individuálnom prístupe je dosiahnutel'ný, hoci v jednoduchej podobe. Predložili sme dve výtvarné práce, ktoré vznikli ako spontánne výtvarné práce žiakov k celoslo- 
venskej sútaži Budimírske studničky v roku 2017. Žiaci uplatnili akvarelovú mal'bu, kresbu a muchláž. Prezentácia na sútaži bola dobrým motívom k výtvarnej tvorbe a oživila tak náročnú prácu s poruchami pozornosti a hyperaktivitou. Bola efektívnym motívom k rôznej výtvarnej činnosti, ktorá siahala až k náročným ciel'om udržat' žiacku pozornost', hoci s prestávkami, čo sa v konečnom dôsledku odporúča v metodike postupov pri ADHD.

\section{Literatúra}

Goetz, M. \& Uhlíková, P. (2013). ADHD porucha pozornosti s hyperaktivitou. GALÉN. Kroupová a kolektiv (2016). Slovník speciálněpedagogické terminologie. GRADA.

Reimann-Höhn, U. (2018). ADHD a ADD v dospívání. Dozrávaní a překonávaní krizí. PORTÁL.

Rietzler, S. \& Grolimund, F. (2016). Ako sa úspešne učit's ADHD. Praktický poradca pre rodičov. NOXI s. r. o. Slowík, J. (2020). Speciální pedagogika. GRADA.

Winter, B. (2018). Jak na ADHD a problémy s pozorností. Praktické tipy pro každý den. Edika.

\section{Informácie o autoroch}

\section{Mgr. Alena Sedláková, Ph.D.}

Pracujem ako odborná asistentka na Katedre hudobnej, výtvarnej a telesnej výchovy, Pedagogickej fakulty, Prešovská univerzita v Prešove, Slovensko. Zaoberám sa výtvarnou výchovou, mal'bou a arteterapeutickým ateliérom, píšem príspevky spojené s výtvarným umením a problematikou špeciálno-pedagogickou.

alena.sedlakova@unipo.sk 